\title{
Wars van dwang. Over de rol van de Raad voor de Kinderbescherming bij de bestrijding van jeugdcriminaliteit
}

\author{
F.J.M. Hoogenboom ${ }^{*}$
}

\section{Ter introductie}

De Raad voor de Kinderbescherming is onderdeel van Justitie en belast met onderzoek en advies wanneer kinderen delicten plegen of in de knel komen in de opvoedingssituatie. In het ene geval wordt ons advies gevraagd over óf en hoe te straffen. In het andere geval geven wij advies aan de rechter over ondertoezichtstelling (ots), uithuisplaatsing of ontheffing van ouders uit het gezag. Ook behoren adviezen m.b.t. gezag, verblijf, omgangsregelingen in scheidings- en omgangszaken tot het werkterrein van de Raad evenals de coördinatie van taakstraffen.

Ik heb een groot deel van mijn loopbaan binnen de Dienst Justitiële Inrichtingen (DJI) gewerkt. Ik werkte en werk in een uitvoeringsorganisatie van Justitie in een managementrol.

Ik werk al lang mee binnen Justitie, voel mij verbonden met acties ter verbetering van het bestaande stelsel. Ik wil het graag goed laten functioneren, kansen en mogelijkheden voor verbetering scheppen en daarbij bedreigingen afwenden en neutraliseren. Ik besef dat de cliënten van Justitie vaak kwetsbare mensen zijn, die vaak meer ondanks zichzelf dan bewust en opzettelijk in de justitiële molens terechtkomen. Uit sommige ontwikkelingen put ik moed, andere ontmoedigen me. Het meest ontmoedigt me de verruwing, stereotypering in de discussie over de aanpak van problemen. Media, pamflettenschrijvers, politici doen daaraan mee. Het wordt allemaal wel erg schreeuwerig en simpel. In dit artikel wil ik het opnemen voor een andere aanpak van jeugdcriminaliteit dan door dwang. Het Makaken-jong

* Drs. Fred Hoogenboom is directeur van de Raad voor de Kinderbescherming directie Noord. 
Ik zag laatst beelden van de opvoeding van apen. Makaken: hoe leren jonge apen de goede dingen te doen en de slechte te vermijden? Ik ga ervan uit dat we daar iets van kunnen leren omdat de mens een verwant zoogdier is. Gedrag heeft een stevige biologische basis. Ik ben er niet al te optimistisch over dat willekeurig uitgeoefende dwang zoveel goede invloed op gedrag heeft, tenzij die uitgeoefend wordt onder condities zoals die in een apenfamilie bestaan: straffen volgt direct op het verkeerde gedrag, het is hard en duidelijk, maar ingebed in een veilige, liefdevolle relatie. Zo zag ik het in een filmpje dat een jonge aap, die eten had gegapt, een ongenadig pak rammel kreeg van zijn moeder, die enkele minuten daarna een verzoenend, wenkend gebaar maakte naar de jonge aap. Daarna vlooiden ze elkaar weer. Hard op de inhoud, zacht op de relatie.

\section{Enkele cijfers}

\section{Criminele carrières}

De badkuipcurve

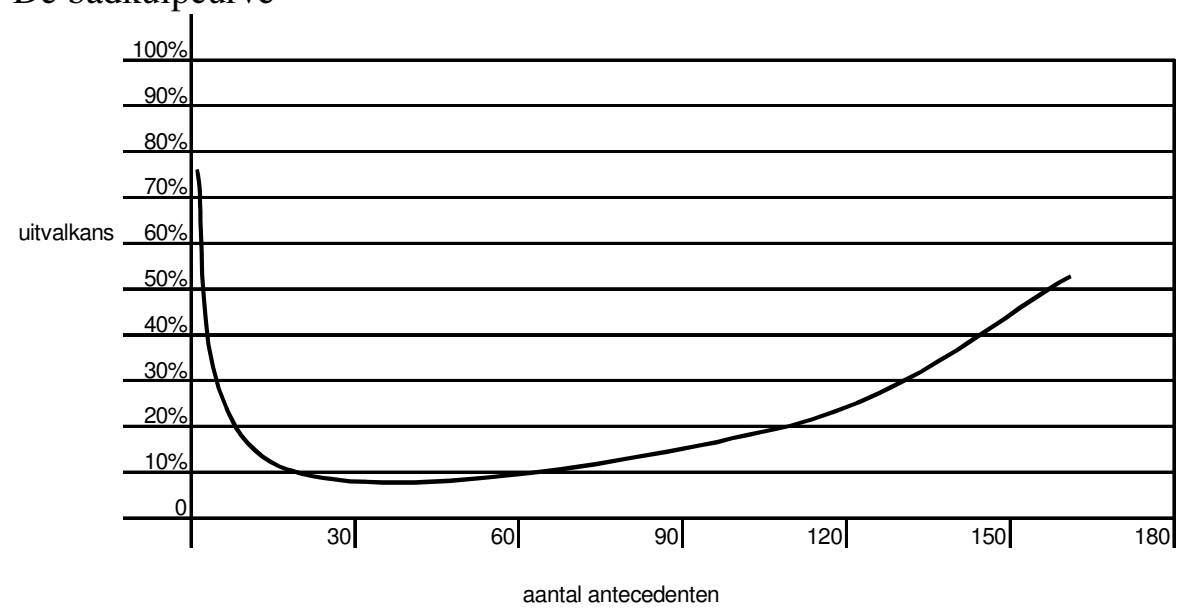

Het OM heeft de zogenaamde badkuipcurve geïntroduceerd om de criminele carrière van mensen in beeld te brengen ${ }^{1}$. Daarin wordt het percentage uitvallers na het eerste delict afgezet tegen het aantal delicten dat gepleegd

1 A. Slotboom en C. Wiebrens, "De komende, blijvende en gaande verdachte" Goed Beschouwd 2003, Openbaar Ministerie, Dan Haag, pp. 15-30 
is. Van volwassen gedetineerden houdt 80 procent het na het eerste delict en de justitiële reactie daarop voor gezien. Ook na een tweede, of derde delict stoppen er veel mee. Dat is de steile kant van het bad. Daarna volgt een bijna vlak horizontaal stuk waarin uitval nauwelijks plaatsvindt. Het ene delict volgt op het andere. Criminaliteit is een deel van het leven geworden. Op enig moment volgt de burn out. De delinquent is er zat van, of te oud geworden, of eindelijk goed geland in het leven. Dat stop-moment verschilt per persoon en dat leidt tot een minder steil oplopen van de grafiek. Jongeren wijken significant af van de totale populatie. Hoe jonger ze beginnen, hoe minder uitval na het eerste delict, hoe groter het risico van een lange carrière, vooral als het gaat om allochtone jongeren, of om jongeren van wie het eerste delict een geweldsdelict is.

Hoeveel delicten worden door jongeren gepleegd, hoe worden ze afgedaan? De populatie jeugdigen in Nederland bestaat uit twee miljoen jongeren tussen 10 en 19 jaar.

Per jaar plegen 16.500 jongeren voor het eerst een zodanig delict, dat ze onder de aandacht van het OM komen. Voor 9300 van hen blijft het bij dit ene incident. Ongeveer 6000 van hen plegen daarna nog één, of enkele (maximaal vijf) delicten. Voor ongeveer 1200 van hen is het begin van een criminele carrière van langere duur, met meer dan vijf geregistreerde incidenten binnen zes jaar.

Van de twee miljoen jongeren tussen 10 en 19 jaar pleegt ongeveer 37 procent in een jaar tijd een delict (750.000) zo blijkt uit zelfrapportage. De politie hoort slechts een klein deel van de daders: in 2002 47.000. In 18.500 gevallen leidde dat aanhouden en horen tot de lichtste vorm van afdoening, namelijk een HALT-verwijzing. In 28.500 gevallen nam het OM de behandeling van de zaak over. Het legde 13.000 zaken aan de rechtbank voor en het legde in 7600 gevallen een taakstraf op (tot 40 uur). In 12 procent van de gevallen werd de zaak geseponeerd. De rechtbank legde nog eens 6500 taakstraffen op, vonniste 1900 maal jeugddetentie en in 200 gevallen een PIJ-maatregel ${ }^{2}$.

De Raad voor de Kinderbescherming voerde in 22.000 gevallen een basisonderzoek uit, en in 3000 gevallen volgde daar een uitgebreider vervolgonderzoek op.

constanten en verschuivingen

2 Plaatsing in Justitiële Inrichting, een soort jeugd tbs. 
- Het aantal HALT-afdoeningen is tussen 1997 en 2002 met 10 procent afgenomen.

- Het aantal zaken dat het OM verwerkt bleef in die periode ongeveer gelijk.

Het aantal basisonderzoeken dat de Raad uitvoert is met 70 procent gestegen.

- Het aantal vervolgonderzoeken bleef ongeveer gelijk.

- Het aantal OM-sepots werd gehalveerd.

- Het aantal taakstraffen verdubbelde.

- Het aantal zaken dat voorgelegd werd aan de rechter steeg met 50 procent.

- Het aantal opgelegde jeugddetenties verdubbelde.

- Het aantal PIJ-maatregelen bleef ongeveer gelijk.

\section{Jeugdstrafrecht-en jeugdbeschermingsstelsel}

\section{Sterke en zwakke kanten}

De sterke kanten van het jeugdstrafrecht zijn de volgende. Er is een redelijk sluitende aanpak. Voor bijna alle daders is er een vervolg na aanhouding en eerste verhoor van de politie. In allerlei processtappen zitten waarborgen opgenomen voor rechtsgelijkheid en rechtszekerheid: gelijke gevallen worden in ongeveer gelijke omstandigheden ongeveer gelijk behandeld. Voor tenminste de helft van de jongeren is het stelsel zo goed, dat criminaliteit een eenmalige zaak is, en ook na tweede of derde delict ontmoedigt het stelsel veel jeugdigen in die mate, dat de criminaliteit snel uitdooft. Het gebruik van alternatieven voor insluiting is regel, opsluiten uitzondering. Het stelsel is in staat zijn productiviteit, en ook de doorlooptijd van zaken te verbeteren, dat geldt ook voor de kwaliteit via verbetering samenwerking in de keten. Er worden veel lichte afdoeningen gehanteerd, met een lagere kans op recidive. Het stelsel ontleent zijn effectiviteit in belangrijke mate aan de kwaliteit, de integriteit en de inzet van de medewerkers, die erbinnen werkzaam zijn.

Waar zitten de zwakke kanten? Het stelsel differentieert te weinig tussen jongeren die een zwaar en een licht risico hebben om een lange criminele carrière door te maken. Het beïnvloedt het criminele carrièreverloop van een fors aantal daders volstrekt niet. Een ander tekort is dat het stelsel onvoldoende leert van zijn successen en mislukkingen. Teveel wordt gewerkt vanuit eigen overtuigingen en niet gevalideerde kennis. Het is 
daardoor gevoelig voor veranderimpulsen van buiten af, en voor mensen, die maar wat roepen. Het is daardoor een speelbal voor de politiek ${ }^{3}$.

Een andere zwakke kant is dat het stelsel er nog onvoldoende in slaagt om een aansluiting te maken met de activiteiten van andere actoren: lokaal bestuur, met zijn verantwoordelijkheid voor de kwaliteit van de leefomgeving, andere maatschappelijke sectoren zoals onderwijs, zorg en hulpverlening. Er vinden nauwelijks geslaagde verwijzingen plaats vanuit het jeugdstrafstelsel naar de jeugdhulpverlening. Het fungeert nog teveel op zichzelf, in een ivoren toren. En het gaat gebukt onder een teveel aan regelgeving.

\section{Een nadere beschouwing over het stelsel}

De aanpak van de jeugdbescherming heeft zijn wortels nog in de negentiende eeuw. De eerst uitgedachte maatregelen zijn gebaseerd op de gedachte dat de overheid de zorg voor verwaarloosde kinderen moet overnemen. Het contact tussen ouders en kinderen moet verbroken worden, of tot een minimum worden beperkt, als ouders niet in staat zijn het kind goed op te voeden en te beschermen. Een andere persoon of een instelling moet die zorg- en opvoedingstaak dan maar overnemen. Later zijn er allerlei genuanceerde maatregelen aan toegevoegd. Dit gekozen uitgangspunt leidde tot veel initiatieven van goedgezinde burgers, en een grote diversiteit van instellingen en opvattingen. De laatste tientallen jaren zijn er veel verbeteringen gerealiseerd: de positie van de cliënt is sterker geworden, er is helderder rolverdeling gecreëerd tussen Kinderrechter, Raad voor de Kinderbescherming als adviseur en in tweedelijnsfunctie, de eerstelijns (jeugd)hulpverlening, met voogdij-instellingen als uitvoerder van maatregelen. Er groeit meer samenhang in het hulpaanbod, lagere overheden worden meer betrokken als eerstverantwoordelijke voor een goed jeugdbeleid. De nieuwe Wet op de Jeugdzorg, die op 1 januari 2005 in werking treedt bevordert vraagsturing, en garandeert een recht op hulp en zorg, met het Bureau Jeugdzorg als indicatorsteller en een regierol voor provincie. De instellingen zijn daardoor verwikkeld in een ingrijpend veranderingsproces, afgedwongen door de politiek, geen oplossing voor de eeuwigheid, maar een beleidsrichting, waarmee verdere verbetering kan worden nagestreefd.

3 Ik heb met bewondering kennis genomen van hoe in een land als Finland het strafrechtelijke systeem voor jongeren en volwassenen sinds de jaren zestig is gemoderniseerd. Gezaghebbende experts, waarin politiek én samenleving vertrouwen hadden, waren de dragers van de veranderingen. 
Het stelsel kan functioneren met meer dwang, maar ook met minder, met meer nadruk op rechtsgelijkheid, of met minder, met meer respect voor de privacy of met minder, met een groter aandeel van de overheid als opvoeder en beschermer of een kleiner, het kan meer verantwoordelijkheid laten bij de ouders of minder. Aan iedere keuze zijn nadelen verbonden. Eenzijdige keuze voor een belangrijk accent op overheidsdwang holt de eigen verantwoordelijkheid van ouders uit. Mijn enthousiasme voor meer overheidssturing wordt gedempt doordat ik weet dat professionele hulpverleners vaak moeilijk toegang krijgen tot gezinnen die diep in de problemen zitten, dat hulpverleners en ouders en kinderen problemen verschillend ervaren, dat veel ernstige jeugdproblemen heel diepe wortels hebben en misschien wel niet opgelost kunnen worden en dat het middel van de ingreep soms erger is dan de kwaal die je probeert te verhelpen.

Als de overheid ingrijpt in gezinssystemen is het bijna altijd een verlegenheidsoplossing: we doen het, omdat we niets anders weten. In die zin heeft deze taak veel gemeen met taken als die van het gevangeniswezen: je sluit op of grijpt in uit onmacht, en je erkent die fundamentele onmacht. Vrees degene die opsluit uit overtuiging! Een onderzoek van Slot $^{4}$ bracht dat ook aan het licht. Een derde van de ots-en werkt goed uit, in een derde van de gevallen helpt het niet, en in een derde vindt er dankzij of ondanks de ots een verslechtering plaats in de situatie van het kind.

Een andere begrenzing aan mijn vertrouwen ligt in de organisatie en professionaliteit van werkers. Jongeren die diep in de problemen zitten ervaren en typeren de hulpverlening als georganiseerde ontrouw, alle goede bedoelingen en inzet ten spijt. Jongeren die problemen hebben, kunnen vaak tientallen hulpverleners noemen die zich met hen bemoeid hebben. Jongeren hebben soms niet in de gaten wat het probleem is waarmee ze geholpen moeten worden. Vooral bij mensen die in een andere cultuur zijn opgegroeid, is dat risico heel groot. Bij kinderproblemen heb je vaak te maken met moeilijk te doorbreken patronen in gezinssystemen, en zelfs slechte gezinssystemen kunnen heel sterk zijn. Er bestaat bovendien weinig zekerheid over het succes van een behandelingsmethode. En die onzekerheid kan ook leiden tot terughoudendheid bij de hulpverlener om te concluderen of te doen wat je eigenlijk zou moeten doen.

4 N.W. Slot e.a.: 909 zorgen. Een onderderzoek naar de doelmatigheid van de ondertoezichtstelling, Vrije Universiteit Amsterdam, november 2001. 
Hoe is het stelsel georganiseerd?

Bij ieder onderzoek naar effectiviteit van jeugdbeleid en aanpak van jeugdcriminaliteit worden de verkokering op rijksniveau, de verdeling van verantwoordelijkheid over vele ministeries, en de verschillende bestuurslagen en financieringsstromen als een fundamenteel probleem beschouwd $^{5}$. De complexe bestuurlijke omgeving waarbinnen en de veelheid en de ingewikkeldheid van de regelgeving waarmee het jeugdbeleid wordt vormgegeven is het belangrijkste, maar ook het moeilijkst op te ruimen obstakel voor verbetering. Het is vooral het laagste bestuurlijke niveau, dat daar last van heeft. En het is de landelijke politiek, die het meest aan de instandhouding van dit probleem bijdraagt. Toch zijn er enkele positieve ontwikkelingen te melden. Vooral in enkele grote steden slaagt het bestuur er in de regie op de aanpak van jeugd-, veiligheids- en criminaliteitsproblemen in handen te krijgen.

De problemen van jeugdigen kunnen in mijn ogen het best worden aangepakt, wanneer op het laagste bestuurlijke niveau (de gemeente) verantwoordelijkheid genomen wordt de oplossing ervan. In dat idee zit misschien iets van nostalgie, verlangen naar de wereld van Bromsnor en de Burgemeester, die hun vinger maar bestraffend hoefden op te heffen om het kwaad te keren. Maar ik heb die mening ook omdat de overlast, de oorzaken, de veroorzakers, zich bij de jeugdcriminaliteit vooral lokaal manifesteren, maar ook omdat de oplossingen lokaal gerealiseerd moeten worden. Als burgemeesters en wethouders zich meer, en justitie-instellingen zich minder eigenaar gaan voelen van het probleem van de jeugdcriminaliteit, kunnen ook op de juiste schaal de afrekenmechanismen tussen burger en overheid gaan werken. Als het laagste politiek bestuurlijke niveau geen adequate sturing weet te geven aan de oplossing van zo'n probleem, wat kun je dan van de hogere politiek bestuurlijke niveaus nog verwachten?

Ik zie dat er zich in de bestuursstructuur en cultuur van het Ministerie van Justitie veranderingen beginnen af te tekenen. Belemmeringen voor samenwerking op regionaal niveau tussen justitieorganisaties worden aangepakt. Het besef is sterker geworden dat het succes van justitie wordt bepaald door het beeld dat de burger heeft van hoe uitvoeringsorganisaties hun werk doen. Ook wordt steeds meer erkend dat de kennis en ervaring die binnen de uitvoerende diensten aanwezig is meer uitdrukking moet krijgen in de besluitvorming over het beleid. Daarnaast zie je de Minister van Justitie in de Kamer worstelen met zijn overtuiging, dat Justitie zich zou

5 Zie bij voorbeeld: Beleid in de groei. Voortgang en uitkomsten van het lokale jeugdbeleid. Sociaal Cultureel Planbureau 2003-15. 
moeten beperken tot zijn kerntaken, en niet meer voor alle problemen in de samenleving verantwoordelijk moet willen zijn. Voor bij voorbeeld nazorg na justitiële interventies zijn lokale overheden, de sociale diensten, welzijnsvoorzieningen, woningcorporaties verantwoordelijk, is zijn uitgangspunt en dat vind ik gezond.

Als onderdeel van het kabinetsbeleid is onlangs de "Operatie Jong", gestart. Die operatie is gericht op het verbeteren van samenhang, ontkokering en samenwerking m.b.t. het jeugdbeleid. In een "Proeve van een Jeugdagenda" zijn de thema's vastgelegd die door de verschillende departementen zullen worden aangepakt om dat probleem van samenhang en coördinatie aan te pakken.

\section{Ontwikkelingen op het terrein van de justitiële interventies}

Kun je de instroom van nieuwe klantjes in het justitiële systeem helpen voorkomen en kun je meer jongeren die op een verkeerde koers zitten, eerder helpen ontsnappen uit dat patroon? Of kun je tenminste de gevreesde groei van die twee groepen afremmen? En hoe moet je dat doen? Ik zal hieronder een aantal ontwikkelingen schetsen, die hieraan kunnen bijdragen. De lengte van die lijst bevestigt overigens nog eens hoe groot het bestuurlijke probleem rond het jeugdbeleid is en hoe divers en complex de problematiek is.

\section{BARO (het basisonderzoek van de Raad voor de kinderbescherming)}

In de jaren zeventig was de aandacht vrij eenzijdig gericht op de invloed van omgevingsfactoren op de criminaliteit. Criminaliteit werd veroorzaakt door de maatschappij, de dader was het slachtoffer. Criminaliteit kon iedereen overkomen, ook in die zin dat iedereen een potentiële dader was. Dat gebeurde onder de invloed van de heersende gelijkheidsidealen. Daarin is verandering gekomen. Er wordt thans onderkend dat niet iedere jongere hetzelfde risico loopt om een delict te begaan, of om een langdurige criminele carrière op te bouwen. Sinds twee jaar hanteert de Raad daarom ook een ander diagnostisch instrument, 'De BARO', waarin dat idee tot uitdrukking wordt gebracht. Het onderzoekt systematisch problemen van jongeren op alle levensterreinen, psychische stoornissen, gezinsomstandigheden, leefsituatie, schoolsituatie, middelengebruik etc. De jongere, de ouders, en - indien mogelijk - belangrijke derden worden bij het onderzoek betrokken. 
Het achterliggende idee is dat er meer naar kritische factoren ín de persoon van de jongere gekeken moet worden, die van invloed zijn op de kans om een (lange) criminele loopbaan te ontwikkelen en wat minder exclusief naar factoren in de omgeving. De BARO moet helpen die risico's vroegtijdig op het spoor te komen, zodat tijdig hulp en steun kan worden geboden, om de kans op een criminele carrière te verminderen. Overigens bleek bij een eerste audit, dat het voor de Raad bij delinquenten met een laag risico veel gemakkelijker is om te adviseren over het vervolg, dan bij de jongelui met een hoog risico. Voor jongeren met een ernstig recidiverisico bleek nauwelijks passende aanpak voorhanden te zijn.

\section{Kwaliteit leerstraffen}

Ongeveer een kwart tot een derde van de taakstraffen wordt ingevuld als leerstraffen. Leerstraffen zijn in verhouding tot werkstraffen duur. Binnen de Raad is net een traject gestart dat binnen anderhalf jaar moet leiden tot een betere inzet van leerstraffen en tot verbetering van de toetsing van de kwaliteit ervan. De leerstraf moet beter gaan aansluiten op de behoefte van de jongeren, en moet relevant zijn in verband met het recidiverisico. Er wordt aansluiting gezocht bij wat (internationaal) onderzoek daarover ons leert.

\section{Verbetering doorlooptijden}

Politie, OM, Haltbureau's, Raad voor de Kinderbescherming werken op arrondissementsniveau samen om snellere afdoening te realiseren. Zestig procent van de HALT-afdoeningen is in 2003 binnen twee maanden na eerste politieverhoor gestart; ongeveer 60 procent van de OM-beoordelingen vindt binnen drie maanden na het eerste verhoor plaats. In 45 procent van de zaken heeft de rechtbank binnen zes maanden na eerste verhoor vonnis gewezen. De (Kalsbeek)norm, die in de loop van 2004, 2005 moet worden behaald is 80 procent. Belangrijk is dat sneller gereageerd wordt op verkeerd gedrag. Maar nog belangrijker is het dat op arrondissementsniveau de partners in de justitieketen op niet-vrijblijvende manier met elkaar gaan samenwerken: doelgroepenbenaderingen uitwerken, doorlooptijden verbeteren. Vanuit deze wijze van samenwerken komen veel impulsen voor verbetering van besturing van de justitieorganisatie. De cynici kunnen zeggen dat er eindeloos vergaderd, gepolderd en gecoördineerd wordt, met ontzettend veel wrijvingsverliezen. Ben je wat opgewekter, dan zeg je dat dit een passend antwoord is op een complexe maatschappelijk probleem. 
Multi System Therapy (MST)

De MST komt overwaaien uit Amerika. De veronderstelling is dat bij kinderen die jong ontsporen, meer problemen aan de hand zijn en dat die in samenhang met elkaar moeten worden aangepakt: het kind met zijn problemen, het gezinssysteem, het kind op school en op straat. De hulpverleners waarborgen de onmiddellijke beschikbaarheid van hulp. Deze aanpak plaatst het kind en de ouders in de bestuurdersstoel. Hulpverleners geven tevoren concreet aan welk resultaat de cliënt kan verwachten en hoe snel dat resultaat naar verwachting bereikt wordt. Deze benadering komt ook tot uitdrukking in het concept "Communities that Care", een aanpak die ook in enkele steden in Nederland gehanteerd wordt.

\section{Eigen Krachtconferenties}

Ik ben zeer gecharmeerd geraakt van deze aanpak die in Nieuw Zeeland, onder Maori's en Canada bij Indianen is toegepast. Juist bij mensen die de aansluiting met de dominante cultuur missen, kan deze aanpak werken. Zorgmijdende gezinnen, die wars zijn van iedere vorm van hulpverlening van buitenaf, of daar al lang hun vertrouwen in hebben verloren, kunnen hiermee worden geholpen om hun problemen de baas te worden. Aan deze gezinnen wordt de vraag voorgelegd, met wie ze samen over oplossingen willen denken. Er wordt een soort bemiddelaar aangewezen, die samen met de gezinsleden gaat bekijken wie mee moeten doen: onderwijzers, buurman, opa, ooms, tantes. Al die mensen worden in een conferentie bij elkaar gebracht. De hulpverleners krijgen de gelegenheid om het probleem zoals zij het zien te schetsen: kindermishandeling, middelenmisbruik, schooluitval, gedragsproblemen. Het netwerk bestaande uit het gezin en degenen die daarom heen staan analyseren de probleemsituatie en spreken met elkaar af, wat ze minimaal willen bereiken, wie wat doet, en wat voor ondersteuning ze daarbij nodig heeft. Het is bij uitstek een aanpak die de eigen verantwoordelijkheid van het gezin en het netwerk eromheen bevordert. Deze conferentievorm wordt in sommige landen ook gebruikt om daders en slachtoffers met elkaar in gesprek te brengen, en wordt gezien als een alternatieve afdoening in plaats van een straf. Het is niet justitieel.

\section{Den Engh en Glenn Mills}

De aanpak in deze instituten is gebaseerd op heropvoeding binnen een groepsstructuur. Er wordt geleerd in het contact met lotgenoten; dwang en intimidatie maken deel uit van de aanpak. Voor beide programma's is een langdurige opname in een inrichting noodzakelijk. Beide aanpakken claimen 
veel succes te hebben bij in beginsel groepsgeschikte, niet zwaar verslaafde en niet zwaar gestoorde jongeren met een criminele levensstijl. Eigenlijk wordt er gebouwd aan een nieuw zelfbeeld. De aanpak wijkt nogal af van de op psycho-sociale en systeemgerichte aanpakken binnen de justitiële jeugdinrichtingen. De Glenn Mills-aanpak komt uit Amerika en bootst de initiatieriten na die in maffiacultuur bestaan. De structuur is hiërarchisch; je kunt opklimmen in rang. Den Engh plaatst groepen jongeren langdurig samen en stelt hen voor moeilijke situaties waarin ze hulp van elkaar nodig hebben. De leidende gedachte achter beide programma's is dat jongeren het meest leren van leeftijdsgenoten. Beide initiatiefnemers hebben de neiging om het succes van hun aanpak te idealiseren. Er kunnen ook kanttekeningen geplaatst worden bij deze aanpak. Onderzoek heeft uitgewezen dat leren in peer-groepen ertoe leidt dat jongeren vooral verkeerde dingen van elkaar leren. Het is bijzonder moeilijk om jongeren met deviant gedrag elkaar positief te laten beïnvloeden. Handhaving van een integere uitvoering van deze programma's kost veel inspanningen. Het succes ten opzichte van ander programma's is moeilijk vast te stellen, omdat het om geselecteerde groepen jongeren gaat.

\section{Cognitive skilltrainingen}

Onder verschillende benamingen zijn de laatste jaren trainingsprogramma's geïntroduceerd, waarvan de kern is: mensen anders leren denken over hoe ze problemen oplossen. Elementen daarvan zijn sociale vaardigheidstrainingen, het leren omgaan met gevoelens van boosheid en agressie, controle op impulsiviteit, het aanleren van in de samenleving geldende normen en waarden. Het zijn langdurige programma's die zowel in residentiele setting als daarbuiten worden gegeven, waarin nieuw gedrag wordt ingeslepen: enkele keren per week, in totaal twintig tot veertig sessies, bij jongeren vaak wat korter dan bij volwassenen, met een looptijd van een half jaar. Toen ik nog bij DJI op beleidszaken werkte heb ik bevorderd, dat we zouden kennismaken met dit oorspronkelijk Canadese model (Reasening and Rehabilitation). In het programma Terugdringen Recidive krijgt een Engelse variant (Enhanced Thinking Skills) nu een plaats. In een aantal penitentiaire inrichtingen waar jongeren en volwassenen verblijven worden samen met de reclassering pilots gestart. Kenmerk ervan is dat de training niet alleen als programma van oefeningen goed in elkaar zit, maar dat ook de trainer's rol goed ontwikkeld is en er veel oefeningen in een motiverende groepsstructuur gedaan worden. Waar ik dit trainingsmodel heb zien werken, zag ik trainers die goed in hun vel en in hun rol zaten (vaak inrichtingswerkers), en bij alle 
voorbeelden die ik heb gezien (in Engeland, Zweden en Canada) was er een zeer stimulerende groepssfeer en groepscohesie opgebouwd. Met alle kanttekeningen die je bij recidivemetingen kunt plaatsen, van deze programma's kun je stellen dat ze significant bijdragen aan vermindering recidive.

Trajectbegeleiding (ITB)

Binnen de jeugdinrichtingen, maar ook binnen gevangenissen heeft de aanpak met de benaming trajectbegeleiding een stevige plaats verworven. De methodiek is goeddeels ontleend aan de begeleiding die ontwikkeld is om mensen met een grote afstand tot de arbeidsmarkt daar toch geplaatst te krijgen. De leidende gedachte is, dat ook delinquenten eigenlijk verlangen naar een gewoon leven met 'werk, woning en wijf'. Stapsgewijs en programmatisch moeten de obstakels die een succesvol maatschappelijk functioneren verhinderen in kaart worden gebracht en opgelost. Het zijn problemen op het gebied van gezondheid, financiën, verslaving en scholing, vaardigheidstekorten, bijvoorbeeld om met geld om te gaan, om met gevoelens van agressie om te gaan, het huis op orde te houden, dingen af te maken of structuur te brengen in de dagindeling. De deelnemers moeten vrij sterk gemotiveerd zijn, maar door in stappen en fasegewijs te werken lukt het vaak om de motivatie te versterken. Er kan in detentie of vanuit een begeleide woonsituatie een begin gemaakt worden. ITB heet soms Individuele Trajectbegeleiding (omdat het gaat om maatwerkprogramma's die vanuit de individuele mogelijkheden en tekorten worden opgebouwd), soms ook Integrale Trajectbegeleiding (omdat de aanpak aansluit op problemen op alle levensterreinen). Workwise, Nieuwe Perspectieven, ook Exodus zijn voorbeelden van zulke programma's. Van groot belang is dat deze trajecten goed geregisseerd worden, dat er warme overdracht is tussen de verschillende fases, en continuïteit, juist die dingen, waarmee het in de jeugdzorg nog niet zo goed gesteld is.

\section{Selectieve aanpak}

$\mathrm{Er}$ is besef gegroeid, dat de ene aanpak beter is voor de ene persoon, en de andere voor de andere persoon. Van een strikt op de heilige regel van de rechtsgelijkheid gebaseerde gelijke behandeling van alle jongeren groeit ook de Raad voor de Kinderbescherming naar een gedifferentieerde aanpak. In 2004 zal de Raad twee miljoen euro besparen door niet iedere jongere even zorgvuldig door de wasmachine van het onderzoek te halen, en door niet in alle gevallen even grondig en uitgebreid te rapporteren. Deze besparing komt neer op vijf procent meer zaken afdoen met evenveel capaciteit. 
Onderscheidingen tussen first offenders en recidivisten, snelle weging van risicofactoren (hoe jonger bij plegen van het eerste delict, hoe meer aandacht) in het casusoverleg, dat met politie en OM gevoerd wordt, moet daaraan bijdragen. Er zijn ook andere redenen om zo'n selectieve aanpak te ontwikkelen, want niet

alleen geldt dat we soms teveel en te zwaar inzetten op lichte gevallen. Ook aan de andere kant tekenen zich problemen af. Bij jongeren die een ernstig recidiverisico vertegenwoordigen, wordt de ernst van de problematiek soms over het hoofd gezien. Dat brengt me bij de volgende te noemen ontwikkeling,

Gerichte aanpak van veelplegers

Het voorbeeld is het HAK-project (Heldere Aanpak Harde Kernjongeren Utrecht). Ik schets een casus, die de zwakte van onze zorgvuldige werkwijze zichtbaar maakt. Een veertienjarige jongen wordt in januari 1999 voor het eerst aangehouden voor winkeldiefstal. Eind 2002, als hij achttien is, staan er dertig aanhoudingen op zijn naam: diefstal, autokraak, vernieling, dierenmishandeling, geweld, belediging. Daarnaast is zijn gedrag goed voor dertien onderzoeken door de Raad voor de Kinderbescherming en acht zittingen op de Rechtbank. Deze jongen is zeven keer veroordeeld tot jeugddetentie, twee keer tot individuele trajectbegeleiding. Hij stond langdurig onder reclasseringstoezicht. Daarnaast is deze jongen 65 maal in beeld geweest, weliswaar niet aangehouden, maar wel geregistreerd als betrokkene of verdachte. Hij valt in de groep jongeren die op verschillende leefgebieden problemen heeft: ze gaan niet of nauwelijks naar school, hebben geen vrijetijdsbesteding en komen uit een moeilijke gezinssituatie. In Utrecht bracht een eenjarig project veertig jongeren met een als hierboven geschetst carrièreverloop in beeld. Verreweg de meeste van hen van Marokkaanse afkomst. Alle informatie die instellingen hebben, is bij elkaar gelegd, knelpunten in de aanpak zijn onderzocht en worden aangepakt. Eilandgedrag, verkokering, gebrek aan communicatie, geen eenduidigheid, al die tekortkomingen in de strafrechtketen worden zichtbaar. De uitkomst van het HAK-project maakt ook dat ik me een beetje schaam. Hoe kan de Raad dertien keer een basisonderzoek doen? Is dat ook de angst om de problemen te benoemen zoals ze zijn: "het is hopeloos met jou, het heeft geen enkele zin om binnen de bestaande structuur onderzoek te doen of in je te investeren". Of zit het vooral op organisatieniveau? Mijn medewerkers zeggen dat dit in de kleine arrondissementen in het noorden op deze manier 
niet gebeurt en dat het een kenmerk is van grote schaal en grote stadsproblematiek.

\section{Kansen en bedreigingen}

\section{Kansen}

Ik schetste rondom ontsporende jeugdigen en de effectiviteit van de huidige aanpak een genuanceerd beeld. Zo is de werkelijkheid ook. Voor veel jongeren is een tik op de neus, een kleine krenking van het gevoel van eigenwaarde, heel heilzaam. Voor die grote groep werkt het sanctiestelsel ook heel goed. Dus we moeten in de eerste plaats gewoon doorgaan met wat we doen. Maar er zijn ook groepen jongeren voor wie onze aanpak niet goed is. We hebben onvoldoende antwoord op de vraag hoe je jongeren moet aanpakken, die door stoornissen, scheefgroei of gewenning aan andere gedragspatronen de band met de samenleving helemaal kwijt zijn of dreigen te raken. Als die al dwang of straf moeten ondergaan dan eerder de dwang of het fysiek geweld van de liefhebbende moedermakaak, dan dwang die opgelegd wordt door een onzichtbare overheid in de vorm van onpersoonlijke maatregelen. Ik geloof ook nog eerder in drang of dwang uitgeoefend door de hulpverlener, die de te helpen jeugdigen (en/of zijn ouders) zelf in de bestuurdersstoel zet. Dat kan werken wanneer die jongere en zijn ouders tegelijkertijd kunnen rekenen op de trouw, de integriteit en de deskundigheid van de hulpverlener.

In het sluitender maken van de samenwerking tussen ketenpartners in de uitvoering liggen de beste kansen voor verbetering van de aanpak van jeugdcriminaliteit. Snellere en betere uitwisseling van informatie, eenvoudige heldere samenwerkingsafspraken, snelle overdracht van zaken op uitvoerend niveau. Op beleidsniveau kunnen resultaatsafspraken gemaakt worden, die niet alleen passen in de planning en controlecyclus van de eigen organisatie (meer processen verbaal), maar die iets duidelijk maken over de resultaten die ketenpartners samen nastreven. Daarnaast is het van belang dat de politieke sturing op de uitvoering van jeugdzorg, jeugdhulpverlening, jeugdstraffen op een zo laag mogelijk niveau, gebeurt, zodat de aanpak aansluit bij de problemen die mensen ervaren.

Uit de feiten, die ik in het voorafgaande gepresenteerd heb, blijkt dat het met de prestaties van dat stelsel niet zo beroerd gaat. Ik denk dat het stelsel beter werkt, wanneer ouders en kinderen zich gerespecteerd voelen, en ouders zich niet van hun verantwoordelijkheid beroofd voelen wanneer hulp goed 
aansluit bij de vraag of behoefte. Wanneer er een laagdrempelige toegang is. De nieuwe Wet op de Jeugdzorg gaat daar op lange termijn zeker een bijdrage aan leveren. Eigenlijk gelden diezelfde voorwaarden voor het ideale stelsel waarmee je criminaliteit van jeugdigen probeert te beïnvloeden; dichtbij, laagdrempelig, in staat tot maatwerk, gericht op de specifieke problemen van de jongeren, onder het motto: Bromsnor en de Burgemeester uit Swiebertje moeten het doen.

\section{Bedreigingen}

Ik noem er drie: stigmatisering, instrumentele in plaats van individuele aanpak en een groeiend aantal jeugdige delinquenten met ernstige persoonlijkheidsproblematiek. Alle hierboven genoemde aanpakken hebben het nadeel dat ze stigmatiserend kunnen werken wanneer ze te zeer onder de noemer van de criminaliteitspreventie worden gepresenteerd. De programma's worden ontwikkeld in een maatschappelijk klimaat, dat op dit moment nog te weinig ondersteunend is om jongeren op het goede pad te houden. Dat klimaat wordt gekenmerkt door individualisering, een sterk hedonistische cultuur van alles moet kunnen, bij ontremmend middelengebruik. De media presenteren prikkelende uitdagende voorbeelden, gezagsstructuren zijn ondermijnd of uitgehold, verantwoordelijkheid is diffuus geworden, er is meer onverdraag-zaamheid en gebrek aan respect voor medemensen dan een generatie geleden.

De wisselwerking tussen burger, media, parlement en overheid leidt ertoe dat de overheid steeds instrumenteler gaat reageren. Daardoor kan een situatie ontstaan waarbij alleen aanpakken die geen risico's in zich bergen en voor honderd procent werken overblijven. Door een jongere bij voorbeeld beter met sociale vaardigheden toe te rusten, kun je bereiken, dat hij in meer situaties uit de problemen kan blijven. Maar omdat er bij criminaliteit altijd meer factoren een rol spelen, kun je op groepsniveau door die trainingen wel een vermindering van de recidive, of uitstel ervan, of verschuiving naar minder zware delicten bereiken, maar geen absolute beëindiging van alle criminele feiten door alle individuele deelnemers. De suggestie dat overheidsingrijpen criminaliteit of recidive kan elimineren is een hele gevaarlijke. Door uitvergroting van incidenten (programma's die op individueel niveau falen), kunnen hele stelseldiscussies op gang gebracht worden. Dat gebeurde naar aanleiding van een brand in Roermond, die was aangestoken door de vader, met als gevolg de dood van zes van zijn kinderen (in 2003) en naar aanleiding van de recente ontvoering van een 13jarig meisje door een tbs-gestelde die niet was teruggekomen van verlof (mei 
2004). Daardoor ontstaat klimaat waarin voor verdere ontwikkeling van professionaliteit, en voor systematisch blijven werken aan verbeteringen op basis van goed langdurig onderzoek geen ruimte meer is. Daardoor ontstaat ook het risico, dan we voortdurend naar nieuwe antwoorden gaan zoeken.

Het uitblijven van duurzame resultaten op heel korte termijn vormt ook een bedreiging. Hierbij hoort een waarschuwing. De problemen rond criminaliteit en ontsporing van jeugdigen zullen niet snel minder worden, wat je ook doet. Dat blijkt uit de ontwikkeling van de bevolking van de justitiële jeugdinrichtingen (opvang en behandeling). Tien jaar geleden waren er 700 plaatsen, nu 2000 en nog is dat niet genoeg. Het zijn inrichtingen die bewaring en crisisopvang en behandeling bieden, niet alleen van justitieel ingesloten, maar ook van civiel ingeslotenen, die nergens anders opgevangen kunnen worden. Het aantal crisisplaatsingen neemt nog steeds sterk toe. In die populatie is het plegen van delicten vaak onderdeel van een ernstige persoonlijkheidsproblematiek die tot uitdrukking komt in antisociaal gedrag, depressieve gevoelens, angst. Zes tot zeven maal zo vaak als bij andere jongeren is er sprake van duidelijk psychiatrische stoornissen, aandachtsstoornissen (al dan niet met ADHD), antisociale gedragsstoornissen, dreigende persoonlijkheidsstoornissen, en middelengebruik.

\begin{abstract}
Afsluiting
Ik heb geen pleidooi voor meer dwang gehouden. Dat komt omdat het systeem waarbinnen we werken naar mijn overtuiging wel redelijk in elkaar zit. Het oplossen van coördinatie-, afstemmings-, samenwerkings- en sturingsproblemen lijkt mij van groter belang dan het ontwikkelen van nog meer nieuwe aanpakken dan al in ontwikkeling zijn. Aanzetten voor inhoudelijke vernieuwing zijn er genoeg. Eerst op lange termijn zal het mogelijk zijn om prestaties en resultaten van het werk van jeugdbescherming, jeugdzorg, jeugdhulpverlening en jeugdstrafrecht zo te bepalen, dat de sector op overtuigende wijze naar buiten kan treden.
\end{abstract}

